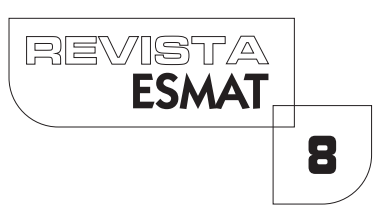

\title{
A INCLUSÃO DE STANDARDS SOCIAIS NOS ACORDOS DA OMC: UM ANTIGO, MAS AINDA CONTEMPORÂNEO DEBATE
}

Ícaro Ivvin de Almeida Costa Lima

Advogado; doutorando em Ciências Jurídico-Econômicas pela Universidade de Coimbra (Portugal); mestre em Ciências Político-jurídicas com menção em Direito Internacional Público e Europeu (Universidade de Coimbra-PT); professor da Graduação da Faculdade Nobre e da graduação e pós-graduação da Faculdade de Tecnologia e Ciências (FTC), de Feira de Santana.

\section{RESUMO}

O presente artigo realiza um estudo acerca da problemática da vinculação de Standards Sociais aos acordos de comércio multilateral da OMC. Analisar-se-á, para tal, o papel assumido pelo Comércio Internacional no contexto da globalização, a importância da Organização Mundial do Comércio neste cenário e a imbricada inter-relação mantida entre os padrões sociais e as relações travadas no âmbito do comércio internacional. Adentrar-seá, então, na análise das principais problemáticas e controvérsias que permeiam a questão da inserção das Cláusulas Sociais no âmbito da OMC. Apreciando, ademais, quais Standards Sociais têm sido propostos e os meios de sua vinculação na OMC.

PALAVRAS-CHAVE: Standards Sociais. Comércio Internacional. Organização Mundial do Comércio (OMC).

\section{ABSTRACT}

This article aims to study about the problematic concerning the inclusion of the Social Standards in the multilateral trade agreements of the WTO. Accordingly, it will analyse the role took on by the International Trade under the context of globalization, the importance of the World Trade Organization in this scenery and the close interrelation that exist between the social standards and the relationships developed under the international trade. Subsequently, it will be analysed the main issues and controversies that underlie the issue of inclusion of social clauses in the WTO. Furthermore, it will be appreciated which Social Standards have been proposed and the means of their connection in the WTO.

KEYWORDS: Social Standards. International Trade. World Trade Organization (WTO). 


\section{INTRODUÇÃO}

O comércio internacional tem desempenhado, desde as grandes navegações, papel de extrema relevância na modelação da realidade econômica, política, jurídica e social dos países. Sendo mesmo o mais importante vínculo entre as diversas nações do globo.

O fenômeno da Globalização e a construção de uma relação cada vez mais interdependente entre os Estados concederam crescente importância ao comércio internacional, fazendo surgir o que se convencionou denominar de Aldeia Global. Nesse contexto, a realidade econômica e social de determinado Estado acaba por deter significativa relevância e influência na construção das realidades econômicas, sociais, políticas e até jurídicas dos demais participantes da comunidade internacional.

Pari passu a essa realidade de globalização econômica e internacionalização do direito, o aprofundamento da urbanização e da industrialização no mundo, a efervescência das ideias socialistas e comunistas, o surgimento das Nações Unidas, bem como a adoção e proclamação da Declaração Universal dos Direitos Humanos ( 1948) contribuíram para a solidificação do paradigma humanista no campo do direito internacional; e fizeram ascender na órbita global amplo arcabouço jurídico em prol da defesa dos Direitos Humanos e Sociais.

Nesse contexto, a repaginação ou relativização do conceito de soberania nacional, a alteração do papel do ser humano na órbita internacional, assim como a ideia de que a defesa da dignidade da pessoa humana (princípio basilar dos Direitos Humanos) traz consigo a necessidade de se estabelecerem padrões jurídicos de proteção mínimos, constituíram-se, então, como os baldrames jurídicos e políticos da proteção internacional dos Direitos Humanos.

Nesse diapasão, o Direito Internacional do Trabalho emerge como o ramo do Direito das Gentes, incumbido de estabelecer padrões internacionais mínimos de relações trabalhistas, com o intuito de promover a dignidade da pessoa humana no âmbito mundial, o bem-estar da humanidade e a justiça social, contribuindo assim para a paz'.

Ante o panorama supradescrito, e cientes da imbricada e indissociável relação existente entre o comércio internacional e as relações sociais e

' PORTELA, Paulo Henrique Gonçalves. Direito Internacional Público e Privado. $3^{\text {a }}$ ed. Salvador: JusPodivm, 201 I, p. 405. 

DEBATE.

trabalhistas, é que, fundados num paradigma humanista de mundo, propõe-se neste módico estudo adentrar na análise da problemática da implementação de Standards Sociais no âmbito da Organização Mundial do Comércio (OMC), buscando percorrer os meandros que permeiam essa temática.

Para tal, realizar-se-á um estudo propedêutico acerca das primevas iniciativas em torno da ideia do estabelecimento de um sistema multilateral de comércio e de uma regulamentação universalizada do comércio internacional - nascidas no seio da ordem econômica internacional forjada após a Segunda Guerra Mundial.

Adiante, far-se-á um sucinto estudo acerca da Organização Mundial do Comércio, delineando sua estrutura básica, principais características e princípios basilares, bem como seu breve histórico. Adentrando, posteriormente, numa análise mais acurada a respeito do seu Sistema de Soluções de Litígios, sua estrutura, funcionamento e importância.

Trar-se-á à tona, então, a questão da fixação de padrões sociais e trabalhistas mínimos, seu breve histórico e os meandros que permeiam a temática; visitando, ademais, experiências no âmbito regional de inserção de cláusulas sociais no seio de acordos e sistemas de liberalização e interação comercial.

Assentados esses fundamentos teóricos e jurídicos, adentrar-se-á no estudo da inclusão de cláusulas sociais na OMC propriamente, levantando as posições contrárias e favoráveis a tal inserção. Buscar-se-á, ainda, avaliar analiticamente quais Standards Sociais devem e comportam ser incluídos neste rol.

Passar-se-á, por derradeiro, à apreciação das formas jurídicas de implementação desses Standards Sociais no seio da OMC, conjecturadas pela doutrina.

Penetrar-se-á, pois, nesse amplíssimo e entusiasmante estudo, que não tem nesta pesquisa o condão nem a pretensão de ser exaustivo, mas, ao contrário, ser apenas uma ponta deste "iceberg" de conhecimento que se descortina aos nossos olhos.

\section{O DIREITO DO COMÉRCIO INTERNACIONAL E ORGANIZAÇÃO MUNDIALDO COMÉRCIO}

\section{Breve Histórico}

Os primeiros empreendimentos visando à promoção de uma reordenação da economia e do comércio mundial surgiram com o fito de mitigar as barreiras comerciais e de estruturar uma ordem econômica mundial sólida, a fim de evitar danos econômicos e crises em escala internacional, assim como buscando 
estruturar um sistema que mitigasse a possibilidade de novos conflitos bélicos na esfera mundial.

Nesse diapasão, já na Conferência de Bretton Woods, de 1944, foi ratificada a necessidade da construção de um sistema multilateral de livre-comércio para a estruturação do sistema econômico mundial no pós-guerra. Não havendo a possibilidade de tratar diretamente do tema durante a conferência, foi sinalizada a convocação de conferência própria para abordar e estruturar a temática nos anos seguintes. ${ }^{2} \mathrm{~A}$ ideia central é a de que a Organização Internacional do Comércio viesse a ser, então, ao lado do Fundo Monetário Internacional (FMI) e do Banco Mundial, um dos três pilares do sistema de Bretton Woods ${ }^{3}$.

As primeiras iniciativas no sentido de se criar uma organização voltada à coordenação do comércio internacional foi trazida à baila na primeira reunião da Comissão preparatória da Conferência sobre Comércio e Emprego das Nações Unidas, em 1946. Nessa oportunidade foram assentados os fundamentos para a constituição de uma organização internacional do comércio 4.

Na reunião de Genebra (1947), 23 países iniciaram as negociações em torno de normas e concessões tarifárias a serem aplicadas nas suas relações e transações comerciais no cenário internacional. Dessa rodada de negociações, originou-se um amplo conjunto de normas e de concessões tarifárias, denominado de Acordo Geral sobre Tarifas e Comércio (GATT). Tal acordo tinha caráter provisório, devendo ser posteriormente incorporado à Carta Constitutiva da Organização Internacional do Comércio (OIC), quando da sua criação.

Durante a Conferência das Nações Unidas sobre o Comércio e o Emprego - ocorrida em Havana entre novembro de 1947 a março de 1948 - foi debatida

\footnotetext{
${ }^{2}$ OLIVEIRA, Ivan Tiago Machado. A ordem econômico-comercial internacional: uma análise da evolução do sistema multilateral de comércio e da participação da diplomacia econômica brasileira no cenário mundial. Disponível e m: <http://www.scielo.br/scielo.php?script=sci_arttext\&pid=S0 I 02-8529200700020000 I > Acessado em 3/6/20I3.

${ }^{3}$ MATOS, Eurico Daniel Lagoa de. Oligarquia: Governação Económica e Ordem Internacional desde $\quad$ I 975 . Disponível e m: <https://estudogeral.sib.uc.pt/jspui/bitstream/I03 I 6/I I 867/I/Disserta\%c3\%a7\%c3\%a30\%2 0de\%20Mestrado\%20de\%20Eurico\%20Matos.doc >. Acessado em 3/6/2013, pp. I2-13; e PORTELA. Direito Internacional Público (...). Op. Cit., p. 358.

${ }^{4}$ OLIVEIRA. A ordem econômico-comercial internacional (...). Op. Cit..
} 

DEBATE.

e confeccionada a Carta de Havana ${ }^{5}$, que tinha por principal desígnio a constituição de uma organização voltada à administração do comércio internacional. Em que pese esta tenha sido aprovada pelos países participantes da conferência, a criação de tal organização ficou atrelada à posterior ratificação da sua carta constitutiva pelos países signatários. Por não conseguir reunir as 27 ratificações necessárias, a natimorta Organização Internacional do Comércio nem sequer chegou a entrar em funcionamento.

Diante do vazio deixado pela OIC, o GATT se converteu no principal marco regulatório do comércio internacional. ${ }^{6}$ Funcionando, para além de um instrumento jurídico, como instituição internacional de fato, com o fito de administrar as relações comerciais internacionais.

Diversas foram as improfícuas tentativas posteriores de criação de organismos internacionais voltados à coordenação e administração do comércio internacional. São exemplos: a) a tentativa da criação da Organização de Cooperação Comercial ( 1955$)$, que, apesar de ter sido elaborado o texto de seu instrumento constitutivo, nunca chegou a vigorar; e b) a ideia da criação de uma Organização Internacional de Comércio formulada pelo então ministro do Comércio Italiano Renato Ruggiero, a qual foi posteriormente convertida em proposta formal do Canadá e apoiada pelas Comunidades Europeias. ${ }^{7}$

Ainda no âmbito do Direito do Comércio Internacional - o qual é parte integrante do Direito Internacional Econômico -, teve relevância a criação da Conferência das Nações Unidas para o Comércio e o Desenvolvimento (UNCTAD). A UNCTAD I ocorreu em 1964 e teve por principais contributos a confecção de uma declaração com os princípios gerais e específicos atinentes à regulação das relações políticas e comerciais internacionais.

A UNCTAD é um organismo internacional vinculado ao sistema das Nações Unidas, de caráter universal, que visa à promoção do comércio internacional orientado ao desenvolvimento e à integração na economia mundial dos países menos desenvolvidos. É uma entidade autônoma, com personalidade jurídica

${ }^{5}$ ORGANIZAÇÃO MUNDIAL DO COMÉRCIO. Conferencia de las Naciones Unidas sobre Comercio y Empleo. Disponível e m: <Http:/Mww.wto.org/spanish/docs_s/legal_s/havana_s.pdf>. Acesso em 22/5/20l3.

${ }^{6}$ MONTAÑÁ MORA, Miquel. La OMC y el Reforzamiento del Sistema GATT. Madrid: McGrawHill, 1997, pp. I-3,7 e II.

${ }^{7}$ Idem, pp. $12-13$. 
própria; sendo, destarte, uma organização subsidiária criada por votação na Assembleia Geral das Nações Unidas, e não por tratado. ${ }^{8}$

Foi por meio da criação da Organização Mundial do Comércio (OMC), entretanto, que o Direito do Comércio Internacional toma maior corpo e forma. Pela OMC foi celebrada e implementada, para além do arcabouço jurídico previsto pelo GATT, uma série de novos acordos e normativas voltadas à regulação das transações, relações e políticas comerciais internacionais. A OMC passa a ser o organismo supervisor e coordenador do comércio internacional multilateral, assumindo papel de proeminência na condução do comércio internacional.

\section{A Organização Mundial do Comércio}

A Organização Mundial do Comércio (OMC) é fruto da codificação e do desenvolvimento progressivo experimentado pelo Direito Internacional do Comércio desde a formação do Acordo Geral sobre Tarifas e Comércio (GATT), assinado em 1947, até a sua criação em 1994, com a assinatura da Ata Final da Ronda do Uruguai, em Marraquexe.

No interregno entre a sua constituição (na Ronda de Genebra, de 1947) e a criação da OMC, o GATT passou por sete rodadas de negociações comerciais, a fim de firmar novos acordos acerca do comércio internacional. ${ }^{9}$

A OMC englobou, portanto, o GATT, de 1947 (com algumas alterações e

${ }^{8}$ MACHADO, Jónatas E. M.. Direito Internacional: Do paradigma clássico ao pós-l I de setembro. $3^{\mathrm{a}}$ ed.. Coimbra: Coimbra Editora, 2006, pp. 507-508.

9 Antecederam a criação da $O M C$ as seguintes rodadas de negociações comerciais: a) Negociações de Annecy (1949), que contou com 13 países participantes; b) Negociações de Torquay ( 195 I), com 38 países participantes; c) Negociações de Genebra (1956), que teve 26 países participantes; d) Rodada Dillon ( $1960-6$ I), com 26 países participantes - tendo sido abordado nessas quatro primeiras rodadas de negociações apenas as questões das tarifas no comércio internacional; e) Rodada Kennedy ( 1964-67), que contou com 62 países participantes e tratou de questões tarifárias e medidas antidumping; f) Rodada de Tóquio ( 1973-79), que teve 102 países participantes e teve por temas as questões das tarifas, medidas não tarifárias e a cláusula de habilitação. Culminando, por FM, na Rodada do Uruguai (1986-94), que contou com 123 países participantes e abordou as seguintes temáticas: tarifas, agricultura, serviços, propriedade intelectual, medidas de investimento; e estabeleceu ainda um novo marco jurídico - a OMC.

A este respeito, vide: ORGANIZAÇÃO MUNDIAL DO COMÉRCIO. The GATT years: from $\mathrm{Ha}$ a a n to Marrakesh. Disponível e m: <http://www.wto.org/english/thewto_e/whatis_e/tif_e/fact4_e.htm > . Acesso em 22/5/20 I3. 

DEBATE.

esclarecimentos interpretativos), os resultados das seis negociações multilaterais de liberalização comercial realizadas desde o GATT, de 1947, até a sua criação, assim como todos os acordos celebrados na Ronda do Uruguai.

Nas palavras do doutor Celso Lafer $^{10}$, a Organização Mundial do Comércio sela também o advento de um novo macrocontexto político, haja vista ter sido formada sob a lógica da globalização e num contexto pós-Guerra Fria.

Nesse sentido, a OMC marca o fim da colisão entre as múltiplas definições do Direito Econômico acerca do Direito do Comércio Internacional existentes até então: em que a União Soviética, representada no âmbito pelo COMECON, compreendia o comércio em âmbito internacional, baseado no comércio administrativo entre Estados por metas quantitativas previamente estabelecidas; o UNCTAD que, representando a concepção dos países do Sul, considera importante a atuação dos estados e dos mercados com o escopo de fortalecer a economia e promover o desenvolvimento; e o GATT, expressando a concepção dos países ocidentais desenvolvidos, compreendia a expansão do mercado por intermédio da liberalização comercial, como o caminho para o crescimento econômico e o desenvolvimento dos países.

A criação da OMC assinala, destarte, a preponderância da ideologia da liberalização das transações comerciais internacionais como melhor via para a condução do comércio internacional, e à realização do crescimento econômico e do desenvolvimento global; marcando, desse modo, a mitigação dos conflitos de concepção supra-indicados ante o fim da Guerra Fria e da "diluição" da polarização do poder mundial ${ }^{12}$.

Tal fato parece ter sido patenteado com o ingresso das duas grandes potências mundiais "socialistas" (ou ex-socialistas) na Organização Mundial: a China, em dezembro de 200 I , e a Rússia, em agosto de 2012 . $^{13}$

A rodada de negociações comerciais em curso entre os países-membros da OMC é a Ronda de Doha ${ }^{14}$. Essa rodada de negociações foi oficialmente lançada na Conferência Ministerial de Doha, no Catar, em novembro de 2001 .

\footnotetext{
${ }^{10}$ LAFER, Celso. A OMC e a regulamentação do comércio internacional: uma visão brasileira. Porto Alegre: Livraria do Advogado, 1998, p. 22.

"Idem, pp. 20-22.

${ }^{12}$ Idem, pp. 22-23.

${ }^{13}$ ORGANIZAÇÃO MUNDIAL DO COMÉRCIO. Members and Observers. Disponível em: < http://wto.org/english/thewto_e/whatis_e/tif_e/org6_e.htm >. Acesso em 22/5/20 I3.

14 ORGANIZAÇÃO MUNDIĀL DO COMÉRCIO. The Doha Round. Disponível em: <http://www.wto.org/english/tratop_e/dda_e/dda_e.htm > . Acesso em 23/5/20 I3.
} 
A Rodada de Doha tem por objetivo produzir ampla reforma no sistema comercial internacional, promovendo a redução das barreiras comerciais e revisando as normas do comércio internacional. Essa rodada de negociações detém amplo leque temático de propostas de trabalho que abrange cerca de 20 áreas do comércio internacional, sendo as principais delas: a agricultura; os serviços; a propriedade intelectual; comércio e desenvolvimento; comércio e meio ambiente; entendimento sobre solução de controvérsias; facilitação do comércio; entre outros temas relevantes.

Por seu claro objetivo de melhorar as condições de comércio e perspectivas comerciais dos países em desenvolvimento, a Ronda de Doha é também conhecida como Agenda de Desenvolvimento de Doha.

A Rodada de Doha promete introduzir, quando concluída, relevantes transformações nas políticas do comércio internacional e nas próprias balizas do Direito do Comércio Internacional. Com destaque não apenas para o aprofundamento da liberalização das trocas comerciais internacionais que será possivelmente implementada por ela, mas também por seu potencial contributo na inclusão de pautas que propiciem o desenvolvimento econômico e social por intermédio da intervenção do sistema comercial internacional, bem como aqueloutras que pugnem pela promoção de uma saudável inter-relação entre o desenvolvimento do comércio internacional e a preservação do meio ambiente.

\section{Características, Objetivos e Princípios Fundamentais da OMC}

A OMC é organismo internacional autônomo que faz parte do Sistema das Nações Unidas, sendo o principal organismo internacional encarregado da promoção da liberalização comercial no mundo.

A Organização Mundial do Comércio é composta atualmente por 159 membros, sendo o Tajiquistão o último país a se tornar membro dessa organização internacional.

A OMC tem por principais funções (ou tarefas): servir de foro para negociações comerciais internacionais; regular o comércio de bens e serviços e áreas correlatas, como os investimentos e a propriedade intelectual; administrar e velar pelo cumprimento dos acordos comerciais internacionais; monitorar os fluxos comerciais internacionais e as políticas internacionais e estatais voltadas ao comércio internacional; promover a cooperação e oferecer assistência técnica em matéria de comércio internacional; examinar e solucionar controvérsias entre os seus estados-membros no que tange à aplicação dos seus acordos e 

DEBATE.

normas de Direito do Comércio Internacional ${ }^{15}$.

Os objetivos da OMC são elencados de maneira genérica e não muito clara no seu preâmbulo, que foi em boa medida retirado do preâmbulo do GATT, de $1947^{16}$. Tal acordo estabelece como objetivos fundamentais a "elevação dos níveis de vida, assegurando o pleno emprego e elevado e sempre crescente nível de rendimento real e de procura efetiva, para a mais ampla exploração dos recursos mundiais e a expansão da produção e das trocas de bens e serviços." Buscando realizar a consecução desses objetivos por meio da promoção da liberalização do comércio internacional, a qual se dará "mediante a conclusão de acordos recíprocos e mutuamente vantajosos, com vistas à redução substancial das tarifas aduaneiras e de outras barreiras às permutas comerciais e à eliminação do tratamento discriminatório, em matéria de comércio internacional." ${ }^{17}$

Destaca, ainda, o doutor Miquel Montañá Mora, com fulcro no comunicado GATT $n^{\circ} 1.636$, de 1994, serem os desígnios de promoção do desenvolvimento sustentável e de preservação do meio ambiente também objetivos da OMC. Leciona aquele professor:

El objetivo anterior debe permitir "al mismo tiempo la utilización óptima de los recursos mundiales de conformidad con el objetivo de un desarrollo sostenible y procurando proteger y preservar el medio ambiente e incrementar los medios de hacerlo, de manera compatible con sus respectivas necesidades e intereses según los diferentes niveles de desarrollo económico". La ocupación por el desarrollo sostenible y la preservación del medio ambiente son ciertamente dos objetivos novedosos, y su mención en el preámbulo pueden constituir dos importantes puntos de referencia a la hora de establecer las competencias implícitas de la Organización. ${ }^{18}$

15 PORTELA. Direito Internacional Público (...). Op. Cit., p. 359-360; ORGANIZAÇÃO MUNDIAL DO COMÉRCIO. What we do. Disponível em: <http://www.wto.org/english/thewto_e/whatis_e/what_we_do_e.htm >. Acesso em 23/5/2013.

${ }^{16}$ MONTAÑÁMORA. La OMC y el Reforzamiento (...). Op. Cit., pp. I4- 16.

${ }^{17}$ ORGANIZAÇÃO MUNDIAL DO COMÉRCIO. General Agreement on Tariffs and Trade. Disponível em: <http://www.wto.org/english/docs_e/legal_e/gatt47_e.pdf>. Acesso em 22/5/2013. (Tradução Livre)

${ }^{18}$ MONTAÑÁ MORA. La OMC y el Reforzamiento (...). Op. Cit., p. 14. 
Segundo as lições do professor doutor Luís Pedro Cunha ${ }^{19}$, o multilateralismo nas relações comerciais internacionais identifica-se no plano institucional com a OMC.

No plano do cumprimento dos princípios fundamentais, esse professor destaca como princípios basilares do sistema comercial multilateral ${ }^{20}$ (e, portanto, da OMC): a) o Princípio da Não Discriminação (o qual se subdivide em duas cláusulas: a. I) Cláusula da Nação mais favorecida; a.2) Cláusula do Tratamento Nacional); b) o Princípio da Proibição das Restrições Quantitativas; c) o Princípio da Liberalização Progressiva do Comércio Internacional; d) o Princípio da Concorrência Leal.

O Princípio da Não Discriminação é o preceito fundamental mais importante do sistema comercial multilateral. Por ele, não é vedada a proteção alfandegária, mas sim a existência de qualquer atuação discriminatória de proteção alfandegária de um país em relação a outro(s). Tal princípio desdobra-se em duas cláusulas:

a) Cláusula da Nação mais Favorecida: tal cláusula visa mesmo coibir a existência de nações mais favorecidas no comércio internacional. Buscando multilateralizar os benefícios alfandegários concedidos por uma nação a outra, estendendo-a a todos os demais países, a fim de garantir uma tarifação igualitária sobre a importação de determinado produto, independentemente da sua origem. Essa cláusula comporta algumas exceções, como nos casos, por exemplo, dos acordos de integração regional;

b) Cláusula do Tratamento Nacional: tal cláusula visa coibir que regulamentações ou imposições internas produzam algum tipo de discriminação do produto importado ante os produtos internos. A proteção ao mercado interno poderá ser feita apenas no momento da importação do produto, por barreiras tarifárias, por exemplo. Não poderá haver, no entanto, a imposição de ônus ao produto importado após o seu ingresso no mercado do país importador. Cumpre destacar, todavia, que tal cláusula impede que regulamentações ou resoluções internas incorram em qualquer tipo de

\footnotetext{
${ }^{19}$ CUNHA, Luís Pedro. O Sistema Comercial Multilateral e os Espaços de Integração Regional. Coimbra: Coimbra Editora, 2008, pp. I5- 17.

${ }^{20}$ Idem, pp. 23-37.
} 

DEBATE.

discriminação desfavorável com relação aos produtos importados, não estando o Estado, entretanto, impedido de criar regulamentações ou imposições internas que onerem apenas os produtos de produção doméstica - o que apesar de admissível, não parece, entretanto, ser postura de larga aplicabilidade na realidade empírica.

Pelo Princípio da Proibição das Restrições Quantitativas, um Estado pode lançar mão, para a proteção comercial da sua produção interna, apenas das medidas de tributação alfandegária. Ou seja, não pode um país proteger a sua produção interna limitando quantitativamente a recepção/entrada de determinado bem ou serviço no seu mercado interno. De outro modo, pelo método de proteção comercial por meio de Restrições Quantitativas - atuação vedada por esse princípio - o estado importador estabelece que, a partir de determinado volume (em moeda, em serviço, ou em mercadoria), cessam-se ou são limitadas as importações.

O Princípio da Liberalização Progressiva do Comércio Internacional, também denominado pela doutrina como Princípio da Redução Generalizada e Progressiva dos Impostos Alfandegários ${ }^{21}$, destaca o objetivo da OMC em fomentar e articular a progressiva redução de barreiras comerciais alfandegárias, visando à crescente e gradual liberalização do comércio internacional.

O Princípio da Concorrência Leal ou Princípio da Proibição do Dumping e dos Subsídios com efeitos na exportação ${ }^{22}$ está previsto nos artigos $6^{\circ}$ e 16 do GATT, e visa garantir um comércio internacional justo e lhano. Tal princípio ganhou maior efetividade com o advento dos Acordos Antidumping ${ }^{23}$, que, além de regularem essas práticas, também previram medidas de desagravo aos danos delas provenientes.

\section{OSistema de Resolução de Controvérsias da OMC}

Sistema de Solução de Controvérsias da OMC logrou alcançar, ao

\footnotetext{
${ }^{21}$ CUNHA. Op.Cit., p. 34.

${ }^{22}$ Idem, pp. 36-37.

${ }^{23}$ KRAMER, Cynthia. Medidas antidumping: devido processo legal à luz das regras da OMC. Tese (Doutorado em Direito Internacional) - Faculdade de Direito, Universidade de São Paulo, São Paulo, 2012, pp. 21 -26.

ORGANIZAÇÃO MUNDIAL DO COMÉRCIO. Agreement on Implementation of Article VI of the General Agreement on Tariffs and Trade 1994. Disponível em: <http://www.wto.org/english/docs_e/legal_e/l9-adp_0l_e.htm >. Acesso em 3/7/20l3.
} 
contrário do seu antecessor (o Sistema do GATT, de 1947), uma estrutura de solução de litígios eficiente, processualizada e efetiva ${ }^{24}$.

$\bigcirc$ atual sistema de resolução de litígios da OMC é o foro exclusivo para a solução de qualquer controvérsia no âmbito dos acordos da OMC, e tem por características a sua abrangência, automaticidade e exigibilidade ${ }^{25}$.

Ampla abrangência, pois todos os acordos da OMC estão cobertos pelo mecanismo.

A automaticidade indica que as etapas da resolução do litígio do mecanismo só podem ser interrompidas por acordo mútuo das partes. Essa característica deriva da regra do consenso negativo ${ }^{26}$ - ora em vigor no âmbito da OMC.

Exequibilidade, significa que a OMC tem a capacidade de fazer cumprir as decisões dos seus órgãos competentes. Ou seja, verificado o descumprimento de uma decisão do Órgão de Solução de Controvérsias (OSC), embasada em relatório do Painel ou do Órgão de Recurso, o membro-demandante poderá solicitar ao OSC autorização para aplicar coativamente os seus direitos comerciais. ${ }^{27}$

Compõem fundamentalmente o Sistema de Solução de Controvérsias da OMC o Órgão de Solução de Controvérsias, os Painéis Especiais, o Órgão de Apelação e o diretor geral da OMC. É possível, entretanto, a participação de Experts em dadas circunstâncias especiais caso se faça necessário; ou até mesmo de árbitros caso as partes envolvidas no litígio desejem lançar mão do procedimento arbitral para a solução de certas questões em várias etapas do procedimento de resolução de controvérsias.

O OSC é órgão permanente vinculado ao Conselho Geral, que tem por principais funções: autorizar a criação de painéis; adotar os relatórios elaborados pelos painéis e pelo Órgão de Apelação; fiscalizar a realização das recomendações e relatórios emitidos pelos Painéis ou pelo Órgão de Apelação; autorizar a suspensão de vantagens e benefícios comerciais para os Estados que tenham violado as regras da $\mathrm{OMC}^{28}$.

\footnotetext{
${ }^{24}$ VARELLA, Marcelo Dias. Efetividade do Órgão de Solução de Controvérsias da Organização Mundial do Comércio: uma análise sobre os seus doze primeiros anos de existência e das propostas para seu aperfeiçoamento. Revista Brasileira de Política Internacional. 2009, Vol. 52, nº 2, pp. 5-21.

${ }^{25}$ PORTELA. Direito Internacional Público (...). Op. Cit., p. 363.

${ }^{26}$ YOSHIURA, Jackson Apolinário. O Sistema de Soluções de Controvérsias da OMC: A aplicação Coativa do Direito. Revista Eletrônica de Direito Internacional. Vol. 6, 20 I 0, p. I 84.

${ }^{27}$ Idem, pp. | 83- I 84.

${ }^{28}$ PORTELA. Op. Cit., p. 364.
} 

DEBATE.

Os Painéis Especiais são órgãos semijudiciais encarregados pela solução dos litígios em primeira instância. São compostos por especialistas na área da demanda e têm entre 3 a 5 membros.

O Órgão de Apelação, por sua vez, é órgão permanente composto por sete membros de notável saber na área do Direito Comercial Internacional. Este órgão é responsável por reexaminar em sede de recurso os aspectos jurídicos das recomendações emitidas pelos Painéis.

O diretor geral da OMC compõe o sistema de resolução de controvérsias podendo oferecer os seus bons ofícios, a fim de contribuir na solução de controvérsias, coordenando tentativas de conciliação ou mediando eventuais litígios no âmbito do comércio internacional entre estados-membros da OMC.

O procedimento padrão de resolução de litígios divide-se, no entanto, nas seguintes etapas:

a) Consultas: Nessa primeira etapa, o estado-demandante deverá comunicar à parte-demandada a controvérsia, a fim de realizar uma tentativa prévia de solução sem que a formação dos painéis/grupos especiais se faça necessária numa espécie de tentativa de conciliação entre estes;

b) Painel Especial: Este será responsável por examinar as reclamações formuladas pelos estados e, com base nos acordos e normas da OMC, confeccionar um painel de recomendações dirigido ao OSC, que poderá adotálo, ou não. Necessitando, nesse caso, do consenso negativo dos membros da OSC para que tal relatório não seja adotado;

c) Apelação: Caso o estado-sucumbente mostre-se inconformado diante do relatório recomendado por qualquer dos mecanismos de solução de litígios da OMC, caberá ao Órgão de Apelação indicar três de seus membros que serão responsáveis pelo reexame dos aspectos jurídicos da demanda em baila. A decisão do Corpo de Apelação deverá ser aceita incondicionalmente pelas partes do litígio caso esta seja adotada pelo OSC. Esse, por sua vez, só poderá não adotar tal decisão pela decisão consensual dos seus membros;

d) Implementação: Adotado o relatório em âmbito irrecorrível pelo OSC, caberá à parte derrotada na controvérsia modificar a sua conduta, compensá-la ou, caso contrário, será penalizado.

O atual sistema de solução de controvérsias da OMC tem mesmo demonstrado alto grau de eficácia. Esse tem alcançado, inclusive, elevado número de soluções amigáveis, com percentuais de soluções conciliatórias muito superiores àqueles obtidos durante os anos do GATT, em que pese o maior grau de institucionalização trazido a esse mecanismo com a Rodada do 
Uruguai. ${ }^{29}$

Destaca-se, portanto, que esse sistema de solução de litígios assume elevada importância no domínio do comércio internacional, haja vista que a existência de um mecanismo eficaz para resolver as controvérsias aumenta o valor prático dos compromissos assumidos pelos países signatários em um acordo internacional. ${ }^{30}$

\section{OS STANDARDS SOCIAIS}

\section{Breve Histórico}

A discussão em torno do estabelecimento de padrões sociais mínimos remonta aos primórdios da Revolução Industrial, e as primeiras movimentações na seara trabalhista em busca da melhoria das condições de trabalho.

A Revolução Francesa, a aprovação da Declaração dos Direitos do Homem e do Cidadão ${ }^{31}$, o surgimento das ideias socialistas modernas e o fortalecimento dos ideários e movimentações sindicais fizeram desenvolver nos países precursores da industrialização um movimento crescente em torno dos direitos do homem e, por conseguinte, da garantia de padrões sociais e condições de trabalho mínimas. Como fruto das conquistas das lutas de classe e das movimentações e transformações políticas ocorridas nesse período, esses valores foram progressivamente incorporados nos corpos jurídicos daqueles Estados Nacionais. Gradualmente, foram sendo erigidos, destarte, verdadeiros arcabouços jurídicos em torno da garantia e da proteção de direitos sociais básicos, a serem amplamente defendidos no domínio estatal.

\footnotetext{
${ }^{29}$ CARNEIRO, Cristiane de Andrade Lucena. Disputas comerciais e magnanimidade: um estudo do mecanismo de solução de controvérsias da Organização Mundial de Comércio à luz da teoria dos movimentos. Contexto Internacional. Rio de Janeiro, v. 30, n³ 3, dez. 2008.

${ }^{30}$ ORGANIZAÇÃO MUNDIAL DO COMÉRCIO. Introducción al sistema de solución de diferencias de la OMC. Disponível e m : <http://www.wto.org/spanish/tratop_s/dispu_s/disp_settlement_cbt_s/cls lpl_s.htm>. Acesso em 4/6/20I3.

${ }^{31}$ A respeito da importância da Revolução Francesa e da Declaração dos Direitos do Homem e do Cidadão para o desenvolvimento dos Direitos do Homem preleciona com a sua peculiar argúcia o professor Noberto Bobbio: "Os testemunhos da época e os historiadores estão de acordo em considerar que esse ato representou um daqueles momentos decisivos pelo menos simbolicamente, que assinalam o fim de uma época e o inicio de outra, e, portanto, indicam uma virada na história do gênero humano.". - in BOBBIO, Noberto. A Era dos Direitos. $9^{a}$ ed.. Rio de Janeiro: Elsevier, 2004, p. 79.
} 

DEBATE.

A relação entre o comércio internacional e os Direitos Humanos já era pautada no século XIX, com a proibição do tráfico negreiro (a fim de combater o trabalho escravo) e na luta pela extinção do trabalho forçado. Igual preocupação é demonstrada quando da celebração do Tratado de Versalhes, em 1919, em que é prescrito aos países signatários que pugnem e atuem no sentido de garantir condições de trabalho justas e humanas na produção de bens destinados à comercialização internacional. ${ }^{32}$

A própria Organização Internacional do Trabalho nasce nesse contexto, com o escopo de estabelecer padrões internacionais mínimos para as relações trabalhistas e condições de trabalho em todo o mundo; visando à melhoria da vida humana como um todo. ${ }^{33}$

Entretanto, o progresso da industrialização pelo mundo, o fenômeno da globalização e os seus efeitos, a vertiginosa expansão do comércio internacional, a mitigação da soberania estatal clássica como consequência da ampliação da inter-relação entre os entes estatais nas órbitas econômica, política e social, dentre vários outros fatores, contribuíram para a ocorrência de uma vasta repaginação da realidade global. Com ela, brotam novas realidades e novas demandas econômicas, políticas e sociais.

Nesse processo, a discussão em torno dos direitos humanos e sociais ganharam mais força no domínio internacional. A interação dessa temática com o comércio internacional alcança contornos ainda mais amplos e um teor de importância muito mais significativo, tendo em vista o papel de proeminência ocupado pelos fluxos comerciais internacionais no mundo globalizado.

A aplicação de cláusulas sociais no âmbito internacional passa, nesse esteio, a ser debatida nos tempos hodiernos não apenas como meio de implementação eficaz e de garantia de diretos sociais mínimos, mas também como forma de proporcionar a realização de uma concorrência comercial justa e leal.

Outrossim, em meio às realidades de intensa competitividade comercial internacional entre as diversas nações do globo, a problemática da implementação de cláusulas sociais em âmbito internacional perpassa agora não mais apenas pela melhoria das condições de trabalho (estabelecimento de

\footnotetext{
${ }^{32}$ KAWAY, Mina; e VIDAL, Pedro Walter G. Tang. Dumping Social: as Normas de Trabalho e sua relação com o Comércio Internacional. Disponível em: <http://www.declatra.com.br/MyFiles/Artigos/Artigo\%20Cl\%C3\%A l usula\%20Social.pdf>. Acesso em 23/5/2013, pp. 5-6.

${ }^{33}$ PORTELA. Op. Cit., pp. 408-4II.
} 
padrões sociais mínimos), mas também pela manutenção das condições e direitos sociais conquistados nos países mais desenvolvidos.

\section{A Cláusula Social no âmbito regional}

A ideia de vincular padrões sociais mínimos no âmbito internacional tem sido vivenciada exitosamente em espaços de integração econômica de âmbito regional, como o Tratado Norte-Americano de Livre Comércio (NAFTA) e a União Europeia.

Na União Europeia tal fenômeno se deu pela adoção da Carta dos Direitos Sociais Básicos dos Trabalhadores, para o estabelecimento de Standards Sociais no campo interno ${ }^{34}$.No domínio externo, pelo estabelecimento de um Sistema Geral de Preferências Tarifárias para países periféricos, o qual condiciona a concessão da preferência ao cumprimento de certas exigências de ordem social.

A Carta dos Direitos Sociais Básicos dos Trabalhadores ${ }^{35}$ foi assinada em 1989, ainda sob a égide das Comunidades Europeias. Tal diploma jurídico estabeleceu os princípios gerais, a fim balizar um modelo europeu de direitos e padrões laborais, aplicando-se essencialmente às seguintes áreas: melhoria das condições de trabalho; proteção social; proteção da saúde e da segurança no trabalho; liberdade de associação e negociação coletiva; condições de emprego e remuneração; igualdade de gênero; proteção das crianças, adolescentes, pessoas de idade avançada e incapacitadas; entre outros. Representando esses, o conjunto de princípios/padrões sociais mínimos comuns a todos os estadosmembros da União Europeia.

No caso do Sistema Geral de Preferências Tarifárias aos países em desenvolvimento, a União Europeia tem considerado algumas práticas, como a utilização de trabalho escravo ou em prisão, como exploração social. A realização de tais práticas na produção de produtos exportáveis implica remoção da preferência tarifária. ${ }^{36}$

\footnotetext{
${ }^{34}$ FRENCH, John D.. A busca de padrões de direitos trabalhistas no comércio internacional. Estudos Avançados. São Paulo, Vol. I0, n²7, ago. 1996, pp. 25I-252.

${ }^{35}$ UNIÃO EUROPÉIA. Community Charter of Fundamental Social Rights of Workers.Disponível e

$\mathrm{m}$

$<$ http://europa.eu/legislation_summaries/employment_and_social_policy/antidiscrimination_re lations_with_civil_society/clol07_en.htm >.Acesso em 5/6/2013.

${ }^{36}$ THŌRSTEN $\overline{E S E N}$, Vera. A OMC - Organização Mundial do Comércio e as negociações sobre comércio, meio ambiente e padrões sociais. Revista Brasileira de Política Internacional. Brasília, v. $41, n^{\circ} 2$, Dec. 1998, p. 46.
} 

DEBATE.

Ademais, desde 1998 esse sistema tem garantido preferências adicionais ao país que demonstre a conformidade de suas práticas trabalhistas com determinadas convenções da OIT - dentre elas estão, por exemplo, a convenção que visa garantir o direito de associação dos trabalhadores e a que trata da idade mínima para o trabalho de crianças. ${ }^{3}$

No caso do NAFTA, os padrões sociais mínimos foram incluídos na esfera regional por meio do North American Agreement on Labor Cooperation ${ }^{38}$ (NAALC). Os padrões trabalhistas incluídos nesse acordo são: segurança e saúde no trabalho, estipulação salarial mínima, vedação ao trabalho infantil, e estipulação de padrões técnicos de trabalho. A liberdade de associação, o direito de greve e de dissídio coletivo não foram incluídos, tendo em vista as restrições do direito coletivo do trabalho mexicano nesse aspecto.

O acordo prevê ainda um sistema de solução de controvérsias com relação à aplicação da legislação laboral de cada país. E mais, institui uma Comissão Trilateral sobre Cooperação do Trabalho, destinada à promoção de atividades concernentes aos temas trabalhistas, ao desenvolvimento de pesquisa e à assistência técnica nesse campo.

\section{A QUESTÃO DA INCLUSÃO DE CLÁUSULAS SOCIAIS NO ÂMBITO DAOMC}

A ideia de se abordarem aspectos sociais e a proteção de padrões sociais mínimos no domínio de organismos voltados ao Comércio Internacional não é algo novo e encontrava-se albergada já na Carta de Havana, que estabeleceu os preceitos basilares da natimorta Organização Internacional do Comércio (OIC). Aquela Carta abordava em seu artigo $7^{\circ}$ acerca de normas visando garantir condições de trabalho justas, nos seguintes termos:

Artículo 7 - Normas de trabajo equitativas

I. Los Miembros reconocen que las medidas relativas al empleo deben tener plenamente en cuenta los derechos de los trabajadores, conforme a las declaraciones, convenciones y convenios intergubernamentales. Reconocen también que todos los países tienen un interés común en el logro y mantenimiento de normas de trabajo equitativas en relación con la productividad $y$, por consiguiente, en el mejoramiento de los salarios y de las

\footnotetext{
${ }^{37}$ Ibidem.

${ }^{38}$ Idem, pp. 48-50.
} 
condiciones de trabajo en la medida en que lo pueda permitir la productividad. Los Miembros reconocen que las condiciones inequitativas de trabajo, especialmente en la producción destinada a la exportación, crean dificultades en el comercio internacional y, por consiguiente, cada Miembro adoptará cualesquier a medidas que sean apropiadas y factibles para hacer desaparecer tales condiciones dentro de su territorio.

2. Los Miembros que lo sean también de la Organización Internacional del Trabajo, cooperarán con esa Organización para dar efectividad a este compromiso.

3. Para todas las cuestiones relativas a las normas de trabajo que pudieran ser sometidas a la Organización, conforme a las disposiciones del Artículo 94 ó 95, la

Organización consultará y cooperará con la Organización Internacional del Trabajo. ${ }^{39}$

Também a questão da inclusão de Standards Sociais na OMC foi proposta na Rodada do Uruguai, com o apoio dos Estados Unidos e de alguns estadosmembros da União Europeia. Tal proposta foi novamente suscitada na Conferência Ministerial de Marraquexe, em 1994, quando da assinatura da ata final da Rodada do Uruguai. Em ambos os casos, sem alcançar êxito.

Em 1996, na Conferência Ministerial de Cingapura, os Estados Unidos e a Noruega apresentaram dois non papers a respeito da questão, propondo basicamente a criação de um Grupo de Trabalho para o exame de padrões trabalhistas fundamentais a serem vinculados no âmbito da OMC. Tais propostas foram prontamente rechaçadas pela maior parte dos países em desenvolvimento e mesmo de alguns países desenvolvidos, por não reconhecerem a OMC como foro apropriado para o tratamento de tal assunto. ${ }^{40}$

A discussão em torno de ser, ou não, a OMC a alçada internacional mais adequada para a regulamentação de tal temática é, indubitavelmente, um dos pontos que abrigam maior controvérsia quando da proposição de se estabelecerem padrões sociais mínimos, com caráter cogente, no domínio internacional.

${ }^{39}$ ORGANIZAÇÃO MUNDIAL DO COMÉRCIO. Conferencia de las Naciones Unidas sobre Comercio y Empleo. Disponível em: $<$ Http:/Nwww.wto.org/spanish/docs_s/legal_s/havana_s.pdf > . Acesso em 22/5/20l3.

${ }^{40}$ LAFER, Celso. A OMC e a regulamentação (...). Op. Cit., p. 57. 

DEBATE.

Os que se opõem a tal ideia defendem essencialmente que a introdução no comércio de temas não relacionados a ele afetaria o processo de liberalização comercial e, por conseguinte, as exportações e a produção de riquezas seriam afetadas, repercutindo negativamente no desenvolvimento econômico. Há, ainda, fortes receios de que tais cláusulas possam se converter em novas formas de protecionismo, prejudiciais aos países em desenvolvimento. Sendo para esses uma forma de violação às vantagens competitivas desses países. Os principais atores dessa tese são os governos dos países em desenvolvimento, as empresas dos países desenvolvidos e os economistas defensores do livre comércio. ${ }^{41}$

Para esse grupo, essas cláusulas devem ser tratadas necessária e exclusivamente na esfera da OIT.

Essa foi a posição firmada no âmbito da OMC, sob a pressão dos países em desenvolvimento, durante a Conferência de Cingapura, nos seguintes termos:

Renovamos nuestro compromiso de respetar las normas fundamentales del trabajo internacionalmente reconocidas. La Organización Internacional del Trabajo (OIT) es el órgano competente para establecer esas normas y ocuparse de ellas, y afirmamos nuestro apoyo a su labor de promoción de las mismas. Consideramos que el crecimiento y el desarrollo económicos impulsados por el incremento del comercio y la mayor liberalización comercial contribuirán a la promoción de esas normas. Rechazamos la utilización de las normas del trabajo con fines proteccionistas y convenimos en que no debe cuestionarse en absoluto la ventaja comparativa de los países, en particular de los países en desarrollo de bajos salarios. A este respecto, tomamos nota de que las Secretarías de la OMC y la OIT proseguirán su actual colaboración. ${ }^{42}$

Em que pese a resistência dos países em desenvolvimento, a questão parece prometer, entretanto, voltar a ganhar força no palco das discussões do comércio internacional, por ser este, tema de declarado interesse dos dois principais atores responsáveis pela definição da "agenda internacional" (EUA e União Europeia).

\footnotetext{
${ }^{41}$ THORSTENSEN, Vera. AOMC (...). Op. Cit., p. 44.

${ }^{42}$ ORGANIZAÇÃO MUNDIAL DO COMÉRCIO. Declaración ministerial de Singapur. Disponível em: <http://www.wto.org/spanish/thewto_s/minist_s/min96_s/wtodec_s.htm>. Acesso em 4/6/2013.
} 
Os favoráveis à inserção de Cláusulas Sociais nos acordos da OMC, entendem que a exportação de bens conduzidos em más condições de trabalho é uma forma de dumping social ${ }^{43}$ e de deslealdade competitiva comercial. Tal atuação comprometeria, assim, a própria manutenção do estágio atual de desenvolvimento dos direitos sociais nos países onde eles se encontram mais desenvolvidos. Advogam essa posição os defensores dos Direitos Humanos, as organizações trabalhistas, os países desenvolvidos, com destaque para os Estados Unidos da América e alguns países europeus. ${ }^{44}$

A problemática da inclusão de Standards Sociais nos acordos da OMC é, portanto, tema que alberga certa complexidade, tendo em vista os meandros que caracterizam tal temática.

O primeiro deles consiste no fato de que em que pese a retórica uníssona do mundo político, econômico e jurídico em torno da defesa dos direitos sociais e humanos e de sua implementação em todo globo, os seus atores têm divergido quanto qual seria o caminho a percorrer a fim de se alcançar tal desiderato: se essas devem ser inseridas no âmbito da OMC ou se deveriam ser tratadas em apartado das questões do Direito do Comércio Internacional; ficando apenas a cargo da Organização Internacional do Trabalho (OIT) a realização de tal desiderato.

Ademais, firmado o entendimento de sua viabilidade, a própria inserção de Standards Sociais nos acordos da Organização Mundial do Comércio suscita reflexões em torno de três principais questões: a) quais standards deveriam e poderiam ser incluídos; b) em que medida eles deveriam ser implementados; c) quais os meios e formas que poderiam ser utilizados para a inclusão dessas cláusulas no seio da OMC.

\footnotetext{
${ }^{43}$ Os defensores da existência de Dumping Social apontam haver, por meio da exploração das desigualdades abruptas de condições laborais entre os países como meio de redução dos custos e ganho e de competitividade pelas empresas, todos os elementos estabelecidas pelo Acordo Antidumping da OMC para caracterização de tal prática, quais sejam: a) venda de produtos abaixo do preço praticado no país exportador (Art. VI do GATT e artigo $2^{\circ}$, II. I , do Acordo Antidumping da Rodada do Uruguai - AARU); b) comprovação do dano ou ameaça de dano à indústria doméstica ou retardamento no estabelecimento de indústrias que venham a produzir o mesmo produto objeto do dumping (Art. VI do GATT e art. $3^{\circ}$, nota de rodapé $n^{\circ} 9$, do AARU); c) nexo de causalidade entre os elementos anteriores (Art. $5^{\circ}$, V. 2, do AARU).

${ }^{44}$ THORSTENSEN. A OMC (...). Op. Cit., p. 44.
} 

DEBATE.

É justamente sobre essas questões que se intentará debruçar mais detidamente a seguir. Buscando, lastreado nas posições doutrinárias acerca do tema, reflexionar sobre elas, colimando encontrar um equinócio convivencial entre as diversas facetas e interesses que permeiam a temática, a fim de procurar o melhor caminho para consecução da implementação de padrões sociais mínimos. Fundar-se-á, para tal, numa visão paradigmática humanista e numa pré-compreensão antropocêntrica de mundo.

\section{Standards Sociais: OMC x OIT}

A apreciação de ser, ou não, a Organização Mundial do Comércio o foro adequado à estabelecer padrões sociais mínimos relacionados ao comércio internacional é de fato questão complexa, mas parece mesmo que se pode apontá-la como a solução mais viável, ao menos por hora, pela inexistência de meios mais eficazes e efetivos para a realização de tal desígnio; senão vejamos.

É inegável o fato de ser a Organização Internacional do Trabalho (OIT) o organismo internacional destinado a pugnar pelo estabelecimento de padrões trabalhistas e pela promoção de melhores condições de trabalho em todo o globo. Além de possuir esta uma ampla e democrática composição, de caráter tripartite, com a participação de representantes dos governos, do empresariado e das associações dos trabalhadores dos seus estados-membros.

Ocorre que a ratificação dos acordos da OIT é voluntário, não tendo muitos dos seus membros nem sequer ratificado um grande número de suas convenções, tampouco diligenciado em busca de implementá-las. Ademais, a OIT não dispõe de meios que garantam de forma cogente a implementação desses padrões. A OMC dispõe, ao contrário, como já exposto, de um eficiente e bem estruturado sistema de solução de controvérsias e de meios de garantia para efetivação dos seus acordos e normas.

Também o simples fato de se conceder à OIT poderes políticos e capacidade sancionadora, como sugere a doutora Vera Thorstensen ${ }^{45}$, não parece ser suficiente para conferir àquela o status de melhor foro para efetivação de tais padrões trabalhistas mínimos relacionados ao Comércio Internacional, por diversos fatores.

\footnotetext{
${ }^{45}$ THORSTENSEN. A OMC (...). Op. Cit., p. 52.
} 
O primeiro deles consiste no fato de que as convenções da OMC preveem padrões demasiadamente amplos e rígidos, o que acaba por inviabilizar na prática a adoção destas no âmbito interno pelos seus estados-membros.

E a temática de Standards Sociais açambarca um conjunto de fatores, interesses e valores a serem tutelados que extrapola a fronteira das questões trabalhistas, alcançando também aspectos econômicos e comerciais.

Basta analisar os aspectos comerciais que permeiam a problemática.

A globalização econômica e dos mercados associada à inobservância de garantia de direitos e condições sociais e de trabalhistas mínimas em alguns países têm, por exemplo, sido utilizadas por diversas empresas como meio de redução dos custos dos seus produtos. Diversas delas têm se aproveitado da utilização e exploração de mão de obra pouco qualificada (muitas vezes sob condições lastimáveis de trabalho), como meio de redução de custos e, por conseguinte, maximização dos seus lucros, conseguindo, por conta disso, inserir os seus produtos no mercado global, inúmeras vezes, com preços muito aquém do próprio custo de produção daqueles mesmos produtos em países com sistemas de proteção laboral desenvolvidos, num ato considerado por muitos como verdadeiro Dumping Social ${ }^{46}$ e de flagrante deslealdade comercial.

Exemplo evidente dessas circunstâncias de abuso e deslealdade comercial são os casos de empresas multinacionais que, com o fito de garantirem os seus altos lucros e simultaneamente ter preços competitivos para inserir os seus produtos no mercado, buscam fixar as suas linhas de produção nos estados que detêm baixa proteção aos direitos trabalhistas, colimando a redução dos seus custos. Para tal, lançam mão, muitas vezes, da utilização de mão de obra em

\footnotetext{
${ }^{46}$ RESENDE JÚNIOR, Vicente de Paula Mendes de. A inserção da Cláusula Social na Organização Mundial do Comércio: uma análise sobre a associação entre o comércio internacional e os padrões mínimos de condição de trabalho. Disponível em: <http://www.bdtd.ucb.br/tede/tde_arquivos/9/TDE-20I3-04-0I T070832ZI 547/PublicoNicente\%20de\%20Paula\%20Mendes\%20de\%20Resende\%20Junior.pdf>. Acesso em 23/5/2013, pp. 50-51.

REIS, Jair Teixeira dos. Organização Mundial Do Comércio - OMC e o Direito do Trabalho. Disponível em: <http://sisnet.aduaneiras.com.br/lex/doutrinas/arquivos/l 60 l07.pdf>. Acesso em 22/5/2013, pp. 2-6.
} 

DEBATE.

condições exploratórias de trabalho, ou até a utilização de trabalho infantil em condições deploráveis e com salários ínfimos. ${ }^{47}$

Alimenta-se, destarte, uma competitividade desleal e transgressora de uma série de padrões sociais e trabalhistas mínimos, lastreada em carências de garantias sociais, visando, unicamente, a um produto com preço final muito abaixo da média praticada pelo mercado global. Circunstância que propaga os seus efeitos perniciosos não apenas na realidade socioeconômica daquele estado em si, mas contribuindo também, em decorrência do fenômeno da globalização, para o decréscimo das conquistas sociais de diversos outros países.

Nesse esteio, parece não ser apenas do interesse da OMC, como também parte do seu objetivo (como se depreende da leitura dos objetivos estipulados no preâmbulo do Acordo de Marraquexe ${ }^{48}$, instituidor dessa organização) a coordenação do comércio internacional em prol do desenvolvimento e da melhoria das condições de vida. Tais objetivos e valores seriam objetivamente pugnados pela estipulação de padrões sociais mínimos vinculados ao comércio internacional, no âmbito dos acordos da OMC. Tendo essa organização um espectro de atuação mais consentâneo com a complexidade que a realidade da inclusão de cláusulas sociais demanda do que a própria OIT.

Os receios, quanto à utilização das Cláusulas Sociais como artifício protecionista, podem ser mitigados, por sua vez, por meio de uma sólida definição dos Standards Sociais a serem implementados e de um rígido e institucionalizado mecanismo de identificação do descumprimento desses preceitos (o qual o Sistema de Solução de Controvérsias propiciaria), reduzindo, assim, a possibilidade de manobras protecionistas por parte dos países desenvolvidos.

\footnotetext{
${ }^{47}$ São exemplos, a utilização de mão de obra infantil pela Nike em fábricas no Paquistão, Vietnã, China e Indonésia; as condições deploráveis de trabalho constatadas numa das empresas responsáveis pela linha de produção da Apple em Taiwan, a Foxconn; e a Samsung, acusada de utilizar mão de obra infantil em um de seus centros de produção (a empresa HEG Electronics), na cidade de Huizhou, na China. Ainda a respeito das condições deploráveis de vida dos trabalhadores em fábricas do sul da China, vide: CHANG, T. Leslie. Factory Girls: From Village to City in a Changing China. New York: Spiegel \& Grau, 2009.

${ }^{48}$ ORGANIZAÇÃO MUNDIAL DO COMÉRCIO. Acuerdo de Marrakech por el que se establece la Organización Mundial del Comercio. Disponível em: <http://www.wto.org/spanish/docs_s/legal_s/04-wto_s.htm>. Acesso em 5/6/2013.
} 
A Confederação Internacional dos Sindicatos Livres (CISL), uma das pioneiras na luta pela vinculação de Standards Sociais ao Comércio Internacional, apresentou excelente proposta prevendo uma interligação entre os processos de monitoramento e reclamação da OIT e o procedimento de reconciliação da OMC. Esta é, por exemplo, uma proposta bastante viável para se poder proceder contra infrações especialmente graves das normas fundamentais do trabalho, mitigando ainda a possibilidade da utilização abusiva da cláusula social por interesses protecionistas. ${ }^{49}$

Nesse sentido, posiciona-se a professora Maria do Socorro A. de Queiroz:

O protecionismo dos países desenvolvidos é motivo forte de preocupação por parte dos países em desenvolvimento, mas não é motivo, sequer razoável, para se evitar medidas efetivas que assegurem o cumprimento dos direitos fundamentais dos trabalhadores no mundo. Ea cláusula social, se bem inserta nos tratados internacionais de comércio e bem administrada pode render grandes frutos em benefícios de todos: Estado, empresários e trabalhadores. ${ }^{50}$

O próprio artigo 20 do GATT, ao tratar das exceções gerais àquele acordo, preocupa-se em vedar a utilização de tais exceções como meio de discriminação arbitrária e injustificada, ou como meio de restrição ao comércio internacional. Podendo ser este também um dos vários caminhos a serem trilhados com o fito de restringir-se a possibilidade de um desvirtuamento protecionista da utilização das Cláusulas Sociais.

Ademais, a inserção de Standards Sociais mínimos por um meio hábil a implementá-lo eficazmente no cenário internacional é, por sua própria carga axiológica de direito humano fundamental, uma imperdível oportunidade de realização de direitos inalienáveis dos indivíduos.

\section{Que são, quais standards, em que medida}

Os Standards ou Cláusulas Sociais são o estabelecimento de padrões mínimos de proteção aos direitos sociais e do trabalho, bem como de condições

\footnotetext{
${ }^{49}$ REICHERT, Tobias. Padrões sociais na economia mundial. Disponível em: <http://www.cocrunder-tisch.de/inhalte/publikationen_rt/Social_standards_global_economy_port.pdf $>$. Acesso em 22/5/2013.

${ }^{50}$ QUEIROZ, Maria do Socorro A. de. A Cláusula Social na OMC: por uma inter-relação efetiva entre OMC e OIT e o respeito aos Direitos Fundamentais dos Trabalhadores. SCIENTIA IURIS, Londrina, v. II, pp. 165-183, 2007, p. 177.
} 

DEBATE.

mínimas de trabalho.

Segundo a Organização Internacional de Normalização (ISO), o termo "padrão" ou "norma" é compreendido da seguinte forma: "Documento estabelecido por consenso e aprovado por um organismo reconhecido, que fornece, para o uso comum e repetitivo, regras, diretrizes ou características para atividades ou seus resultados, visando à obtenção de um grau ótimo de ordenação em um dado contexto. ${ }^{5}$

A inserção de Standards Sociais no comércio internacional colima, destarte, o estabelecimento de uma normativização mínima dos direitos trabalhistas fundamentais e das condições de trabalho, visando à melhoria das relações e condições de trabalho em seu aspecto qualitativo, assim como a garantia de condições justas e leais de competitividade no comércio internacional.

O núcleo duro da discussão em torno dos padrões sociais relacionados ao comércio internacional tem, com o fito de mitigar divergências, se encaminhado a centrar-se essencialmente em quatro standards básicos, quais sejam: a liberdade de negociação e associação, o trabalho infantil, o trabalho forçado e a não discriminação. ${ }^{52}$ Há, entretanto, proposições que estendem consideravelmente este rol para abarcar a questão da inspeção de mão de obra e da segurança e saúde no trabalho ${ }^{53}$, por exemplo.

Compreende-se, no entanto, que a definição de quais cláusulas sociais devem ser inseridas no âmbito da OMC necessita passar, impreterivelmente, pela busca de um equilíbrio convivencial entre os diversos interesses e valores em causa.

Não se deve chegar a um extremismo utópico de buscar elencar um elevado número de direitos trabalhistas básicos. Todavia, não parece prudente se furtar de discutir padrões essenciais que afetam diretamente questões nevrálgicas que permeiam a interconexão entre as condições sociais laborais e o comércio internacional, como a questão de se estabelecer um padrão remuneratório mínimo.

${ }^{51}$ Organização Internacional de Normalização; cit. conforme ABNT, ISO/IEC. Guia 2 Normalização e Atividades Relacionadas - Vocabulário Geral; 1998.

${ }^{52}$ SENA JÚNIOR, Roberto Di. Comércio Internacional e Padrões Trabalhistas: a Falácia do Discurso Humanitário. Revista Seqüência. No 46, pp. I 21 - | 40, jul. de 2003, pp. I26- I 27.

${ }^{53}$ FRENCH, John D. . A busca de padrões (...). Op. Cit., p. 262. 
Os Standards elencados devem permitir a garantia dos padrões sociais mínimos desejados e propiciar a realização de um comércio internacional justo e que cumpra, por conseguinte, o seu objetivo desenvolvimentista, mas, simultaneamente, devem primar por não implicar perda de competitividade para os países menos desenvolvidos.

A inserção de tais cláusulas deve, ao contrário, atentar para os diferentes estágios de desenvolvimento econômico e social em que se encontram os diversos estados, bem como respeitar as peculiaridades culturais e religiosas de cada país.

Norteado por esse entendimento, parece pertinente a inclusão dos seguintes standards: i) proibição do trabalho forçado e do trabalho escravo; ii) não discriminação de gênero quanto às condições de emprego e remuneração; iii) trabalho infantil; iv) liberdade de associação dos trabalhadores e de negociação coletiva; v) remuneração mínima.

\section{Proibição do trabalho forçado e do trabalho escravo}

A Convenção 29 da $\mathrm{OIT}^{54}$, sobre a abolição do Trabalho Forçado, o define, em seu artigo $2^{\circ}$, como "todo trabalho ou serviço exigido de uma pessoa sob a ameaça de sanção e para o qual não se tenha oferecido espontaneamente".

O Trabalho Forçado e o trabalho escravo (ou análogo ao escravo) constituem, inegavelmente, condições de trabalho intoleráveis no mundo atual.

A liberdade e a dignidade da pessoa humana, como bens jurídicos primordiais a serem tutelados, são frontalmente ofendidos por esses dois tipos de trabalho.

A inclusão de uma cláusula de vedação ao trabalho escravo e forçado deveria, no entendimento deste aluno-autor, ser incluída com vista ao combate de modo irrestrito e efetivo àquele primeiro e de vedação ao segundo nos moldes previstos pela Convenção (29) sobre o Trabalho Forçado e a Convenção ( 105 ) sobre a Abolição do Trabalho Forçado, ${ }^{55}$ ambas da OIT.

\footnotetext{
${ }^{54}$ ORGANIZAÇÃO INTERNACIONAL DO TRABALHO. Convenção (29) sobre o Trabalho Forçado ou Obrigatório. Disponível e m: $<$ http://www.oit.org.br/sites/all/forced_labour/oit/convencoes/conv_29.pdf >. Acesso em 6/6/2013.

${ }^{55}$ ORGANIZAÇÃO INTERNACIONAL DO TRABALHO. Convenção ( I 05) sobre a Abolição do Trabalho Forçado ou Obrigatório. Disponível em: <http://www.ilo.org/dyn/normlex/en/f?p=NORMLEXPUB:I2100:0::NO:I2100:PI2100_IN STRUMENT_ID:3 I2250:NO>. Acesso em 6/6/2013.
} 

DEBATE.

\section{Não discriminação de gênero quanto às condições de emprego e remuneração}

A questão da não discriminação de gênero é questão complexa, haja vista as diferenças culturais e pré-compreensões de mundo diversas. Há mesmo de se respeitarem ainda questões de foro religioso.

Isso porque é inconcebível em meio ao mundo islâmico ou judeu, por exemplo, a afirmação e luta pela plena igualdade de condições entre homens e mulheres.

Não se olvida, no entanto, as diversas mazelas que a desigualdade entre os sexos tem causado às mulheres è̀ sociedade como um todo.

O prêmio nobel, Professor Amartya Sen, chega a abordar em seus estudos a inter-relação existente entre a desigualdade entre os gêneros e o fenômeno da excessiva mortalidade e das taxas de sobrevivência artificialmente baixas das mulheres no mundo subdesenvolvido. ${ }^{56}$

Diante dessa complexa realidade, compreende-se que a inserção do princípio da não discriminação, consagrado no artigo $1^{\circ}$ da Declaração Internacional dos Direitos Humanos, admitiria ser inserido enquanto standard social no seio do comércio internacional apenas no que tange vedação à discriminação de condições de emprego e de remuneração.

A Convenção $n^{\circ}$ || | sobre a discriminação em matéria de Emprego e Profissão da OIT e a Convenção n ${ }^{\circ} 100$ sobre Igualdade de Remuneração da OIT tratam, respectivamente, desses Standards.

\section{Trabalho Infantil}

Dados do Fundo das Nações Unidas para a Infância (UNICEF) apontam que cerca de 246 milhões de crianças estão envolvidas no trabalho infantil no mundo atualmente. Dessas, aproximadamente 70\% (I7I milhões) desempenhando trabalhos de risco e/ou em péssimas condições.

A questão do trabalho infantil é tema de elevada complexidade, haja vista que, na realidade de muitos países em desenvolvimento, a inserção da criança

\footnotetext{
${ }^{56}$ SEN, Amartya. Desenvolvimento como Liberdade. São Paulo: Companhia de Bolso, 20 I 2, p.p. $|4|-\mid 45$.

${ }^{57}$ UNICEF. Factsheet: Child Labour. Disponível em: <http://www.unicef.org/infobycountry/files/child_labour.pdf>. Acesso em 6/6/20 I3, p. I.
} 
no mercado laboral é mesmo condição de subsistência do seu núcleo familiar.

Entretanto, há algumas espécies e condições de trabalho infantil que decorrem em condições deploráveis e desumanas ou mesmo em atividades ilícitas. Ou ainda aquelas que detêm mesmo condição bestial dada a sua aproximação com a adscrição de trabalhadores e de escravidão efetiva. ${ }^{58}$

Nesses casos, parece ser pertencente à ética geral que essas são espécies de trabalho que necessitam mesmo ser abolidas.

Outrossim, estudos no campo da Psicologia ${ }^{59}$ têm reiteradamente indicado que a inserção de crianças de tenra idade no mundo laboral contribui para a formação de crianças e adolescentes sofridos, com dificuldades de aprendizado e atenção, explorados, consumidos, autonomizados e adultizados, dentre vários outros prejuízos. Daí a necessidade de se estabelecer também uma idade mínima para a aceitação do trabalho juvenil.

A própria UNICEF não se opõe à participação da criança e do adolescente no mercado de trabalho em termos absolutos, mas sim a inserção destes em trabalhos que comprometam a sua saúde física e psíquica. E desde que respeitada a idade mínima de doze anos. A partir desta idade é aceita pela UNICEF a participação da criança em atividades de trabalhos leves, desde que não interfira em sua educação. ${ }^{60}$

Nesse diapasão, a adoção de uma cláusula social atinente ao Trabalho Infantil na OMC dever-se-ia restringir à vedação da utilização do trabalho infantil em situações de risco ou degradantes, bem como a limitação de idade e condições para a participação de crianças no mercado de trabalho, em moldes similares àqueles preconizados pelo artigo $3^{\circ}$, alíneas "a" e "d" "61, da Convenção n' 182 sobre as piores formas do Trabalho Infantil da OIT e pela Convenção n 138 sobre a Idade Mínima de Admissão ao Trabalho da OIT.

Crê-se, entretanto, que tal standard - pela sua amplitude e impacto na realidade do comércio internacional e pela complexidade das questões de âmbito socioeconômico que envolvem a matéria do trabalho infantil -, caso

\footnotetext{
${ }^{58}$ SEN, Amartya. Desenvolvimento (...). Op. Cit., p. 155.

${ }^{59}$ ALBERTO, Maria de Fátima Pereira; e SANTOS, Denise Pereira dos. Trabalho infantil e desenvolvimento: reflexões à luz de Vigotski. Disponível em: <http://www.scielo.br/scielo.php?script=sci_arttext\&pid=S | 4 | 3-737220 | | 000200004>. Acesso em 6/6/2013.

${ }^{60}$ UNICEF. Factsheet: Child Labour. Disponível em: $<$ http://www.unicef.org/infobycountry/files/child_labour.pdf>. Acesso em 6/6/20 I3; p. 4.

${ }^{61}$ Destacam-se apenas essas, haja vista que as demais circunstâncias elencadas naquela convenção não são compatíveis com a realidade do comércio internacional formal e lícito, o qual é o objeto de coordenação e supervisão pela OMC.
} 

DEBATE.

implementado no âmbito da OMC, deveria sê-lo por meio de metas progressivas de ajuste a tais padrões. Associando ainda o cumprimento de tais padrões a planos de incentivos comerciais aos países que adotassem medidas paralelas em prol da mais célere e eficaz realização de tais padrões ${ }^{62}$.

\section{Liberdade de Associação dos Trabalhadores e de Negociação Coletiva}

A liberdade de associação dos trabalhadores é mesmo direito básico inerente às liberdades do indivíduo, merecendo tão somente por isso amplo albergue jurídico.

Ademais, a liberdade de associação é o "veículo" básico para condução dos trabalhadores à conquista de novos direitos e à melhoria das condições suas condições de trabalho.

Como sabiamente vaticinou o grande filósofo da Filosofia Moderna Baruch Spinosa: "Cada um tem tantos direitos segundo o poder que tem.".

Os direitos de associação e de negociação coletiva são mesmo o baldrame sob o qual se alicerçam todos os meios de exercício do poder de atuação coletiva dos trabalhadores. São, ainda, a força motriz para a construção de novas conquistas de garantias e direitos na seara laboral.

A garantia da liberdade de associação e de negociação coletiva por meio de um standard social vinculado à OMC é a base para o desenvolvimento posterior de outros direitos trabalhistas coletivos, como o direito de greve, de dissídio coletivo, entre outros.

É, destarte, condição sine qua non a concretização de um ambiente laboral e produtivo justo e, por conseguinte, de um sistema comercial concorrencial leal.

A Organização Internacional do Trabalho celebrou diversas convenções destinadas a garantir o direito de associação e sindicalização dos trabalhadores, são algumas delas: Convenção no | | da OIT, sobre o direito de Associação dos trabalhadores agrícolas; Convenção no 87 da OIT, sobre a liberdade Sindical e a proteção do direito de sindicalização; Convenção no 98 da OlT, sobre o direito de Sindicalização e negociação coletiva; Convenção $n^{\circ} 141$ da OIT sobre as organizações de trabalhadores rurais.

\footnotetext{
${ }^{62}$ Estudos indicam que uma atuação efetiva de combate à mão de obra infantil deve contar, no plano estatal - para além de uma eficiente aplicação da norma jurídica coibidora de tal prática com políticas de subsídio à educação e de crescimento do parque tecnológico industrial daquele país. Nesse sentido, vide: BELLETTINI, Giorgio; CERONI, Carlotta Berti; e OTTAVIANO, Gianmarco I. P. Child Labour and Resistance to Change; in Economica. London: LSE, Volume 72, Number 287, August-2005.
} 


\section{Remuneração Mínima}

Cláusula Social que detém alta relevância prática para a promoção de um cenário comercial global mais justo e para uma efetiva garantia de padrões mínimos de dignidade no âmbito laboral.

Ademais, remunerações aquém de um valor que possibilite condições mínimas de sobrevivência em determinado estado - tais quais: alimentação, vestuário e moradia - são de fato condições de trabalho análogas à escravidão.

O estabelecimento de um standard com vistas à realização de um padrão de remuneração mínima é, indubitavelmente, um importante passo para se criar um ambiente produtivo mais justo e para a promoção do desenvolvimento social.

A inserção de uma cláusula voltada à criação de um salário mínimo universal é, entretanto, flagrantemente inviável, tendo em vista as diferentes realidades sociais e os diferentes estágios de desenvolvimento econômicos dos diversos países.

A ideia de uma cláusula social atrelada ao comércio internacional, referente a uma remuneração mínima, deveria centrar-se, no entendimento deste alunoautor, na criação de um parâmetro global de construção de um padrão remuneratório mínimo consentâneo à realidade socioeconômica de cada estado.

Um modelo interessante a ser seguido seria a estipulação de um standard social que determinasse a criação de um padrão remuneratório mínimo (um salário mínimo) vinculado ao valor de um cabaz básico de bens necessários à sobrevivência do trabalhador, devendo este ser estipulado segundo a realidade socioeconômica de cada país.

Colimando manter um padrão de incentivo ao desenvolvimento econômico-social progressivo, a correção desse salário mínimo passaria a ser corrigido (anual ou bianualmente) de acordo com o valor da inflação do(s) ano(s) anterior(es), somada a variação do PIB (Produto Interno Bruto) real ${ }^{63}$ de dois anos anteriores. ${ }^{64}$

\footnotetext{
${ }^{63}$ Adotou-se aqui o Produto Interno Bruto (PIB) real ao invés do PIB nominal como índice balizador, tendo em vista possibilitar uma avaliação objetiva do crescimento físico real da economia, isento dos efeitos dos aumentos dos preços.

${ }^{64}$ Esse tem sido, em linhas gerais, o método de correção salarial adotado pelo governo brasileiro desde 2000. Vide: BRASIL. Direitos do Trabalhador: Salário Mínimo. Disponível em: <http://www.brasil.gov.br/para/servicos/direitos-do-trabalhador/salario-minimo>. Acesso em 4/6/2013.
} 

DEBATE.

Esse modelo tem o benefício de assegurar uma remuneração mínima à condição de vida do trabalhador, bem como um progressivo ganho real de remuneração de acordo com as ondulações do crescimento econômico do seu país.

Outrossim, tal método teria ainda o condão de proteger a remuneração do trabalhador da redução/perda do seu poder aquisitivo em face dos fenômenos inflacionistas.

Essa indexação de padrão remuneratório à realidade econômica dos países contribuiria inquestionavelmente para a consecução do objetivo de um setor produtivo mais justo e um comércio internacional mais leal. Quanto a este último, se considerado numa análise linear, na qual se avaliam tão somente os aspectos de extrema desigualdade de padrões sociais e trabalhistas como óbice à competitividade comercial, como é sabido, está longe de ser uma verdade!

Pensando no aspecto social da inserção de tal standard, cumpre destacar que não se olvidou que os contributos da estipulação de um salário mínimo para a redução da pobreza e da desigualdade em determinado estado são minimizados caso não seja acompanhado de políticas que garantam o movimento crescente do nível de emprego ${ }^{65}$; para que sua estipulação não constitua um veículo ao desemprego ou à informalidade.

Sabedores da relação econômica existente entre a taxa de crescimento do PIB e a variação da taxa de desemprego (a chamada Lei Okun), onde é demonstrado que o elevado crescimento do produto associa-se tipicamente à diminuição da taxa de desemprego, e vice-versa, ${ }^{66}$ pugnou-se que a implementação de tal standard (remuneração mínima), na OMC, deve vir acompanhada de uma política de incentivos ao comércio internacional daqueles países que, não tendo previamente definido em seu território a existência de um salário mínimo, implementem-no. Isso com o escopo de, fortalecendo o seu potencial exportador, que esses países possam elevar o seu crescimento econômico e, por conseguinte, o seu desenvolvimento social.

\footnotetext{
${ }^{65}$ MENEGUIN, Fernando Boarato; e AMARO, Meiriane Nunes. Política de salário mínimo: efetividade, condicionantes e alternativas. Disponível em: $<$ http://www2.senado.leg.br/bdsf/bitstream/handle/id/834/RI 57-03.pdf?sequence $=4>$. Acesso em 28/5/2013, pp. 68-69.

${ }^{66}$ TIMM, Luciano Benetti (organ.). Direito e Economia no Brasil. São Paulo: Editora Atlas, 2012 ,
} 


\section{Formas e instrumentos jurídicos para a implementação dos Standards Sociais}

As Cláusulas Sociais podem ser aplicadas de forma positiva ou negativa.

Como forma negativa, o emprego da cláusula social tem por consequência o seu descumprimento à aplicação de sanções consistentes na limitação ou proibição das importações, ordinárias ou preferências de produtos do país violador dos padrões sociais mínimos estipulados. E positiva, quando haja a concessão de benefícios e/ou incentivos aos países que tenham observado e efetivado os padrões sociais por ela estabelecidos. ${ }^{67}$

Compreende-se que uma aplicação eficiente de tais Standards Sociais no seio da OMC perpassaria pela aplicação das cláusulas sociais com uma dupla forma, estipulando sanções àquele país descumpridor do padrão social previsto - respeitado um prazo progressivo de adaptação a esses padrões, de acordo com a realidade de cada grupo de países (desenvolvidos, em desenvolvimento, ou subdesenvolvidos -; bem como concedendo benefícios e incentivos àqueles países que demonstrem efetivo esforço de implementação das cláusulas sociais por múltiplas atuações, ou mesmo antecipem-se ao estágio progressivo de ajustamento aos Standards previsto para ele naquele determinado período.

Quanto aos meios de inserção dos Standards Sociais, a professora doutora Vera Thorstensen ${ }^{68}$ aborda em primorosa síntese as várias propostas sobre os meios pelos quais essas cláusulas poderiam ser incluídas nas regras da OMC, quais sejam:

- antidumping - dentro do Artigo VI do GATT 1994 - como uma forma de introduzir o produto em um membro, com preços abaixo do valor normal, e, assim, de forma considerada desleal;

- anti-subsídio - dentro do Artigo VI e XVI do GATT 1994 - como uma forma de subsídio do governo, ao permitir condições trabalhistas em níveis muito baixos;

${ }^{67}$ SILVA. Eveline de Andrade Olivera e. A Cláusula Social no Direito Internacional Contemporâneo. Disponível e m : <http://repositorio.uniceub.br/bitstream/I23456789//490/I/EVELINE.pdf>. Acesso em 23/5/20।3, pp. 38-39; e REIS. Organização Mundial Do Comércio (...). Op. Cit., p. 8.

${ }^{68}$ THORSTENSEN, Vera. A OMC (...). Op. Cit., pp.5I-52. 

DEBATE.

- exceção às regras gerais - dentro do Artigo XX do GATT 1994 - como uma exceção às regras gerais de restrição às importações, a ser incluída nos casos já previstos de proteção à vida humana, animal ou vegetal, segurança, trabalho de presidiários, e conservação de recursos exauríveis;

- anulação ou prejuízo de benefícios - dentro do Artigo XXIII do GATT 1994 - sob a alegação de que os benefícios derivados de uma negociação estão sendo anulados ou prejudicados.

Essa professora refere ainda que a inclusão dos Standards Sociais, por intermédio do Artigo XXIII (Anulação ou prejuízo de benefícios), seria, dentre as possibilidades supraelencadas, um eficiente meio de implementá-los. Isso porque este é um mecanismo multilateral da OMC que exige a interferência do Órgão de Solução de Controvérsias, havendo consulta entre as partes e também consultas no seio da OMC. Tal procedimento incluiria uma investigação, recomendação e, se for o caso, a prática de retaliação autorizada. Envolveria ainda, neste caso, a necessidade de outras instituições, assegurando, assim, a participação da OIT em eventuais controvérsias.

Os atores contrários à inserção das cláusulas sociais nos acordos da OMC alegam, entretanto, que a introdução dessas acabaria por sobrecarregar o Sistema de Solução de Controvérsias com assuntos externos aos interesses do comércio internacional.

Esses aparentam ser, todavia, argumentos de bases frágeis.

Em primeiro lugar, pois, como evidenciado neste estudo, o comércio internacional mantém um relacionamento imbricado e de mútua influenciação com as questões sociolaborais.

É inolvidável ainda ser do próprio objetivo expresso da OMC a melhoria das condições de vida e o fomento do desenvolvimento. Objetivos aos quais a implementação das cláusulas sociais conferiria inegável contributo à sua realização. Sendo, destarte, um pequeno "custo" a ser arcado ante os benefícios dele advindos.

Ademais, limitar a realização de um dos escopos declaradamente primordiais da OMC sob a simplória justificativa de não sobrecarregar o sistema de solução de controvérsias consubstanciaria uma verdadeira limitação de fins para salvaguardar os meios. Num tosco exemplo, é como se o legislativo devesse abster-se de legislar novos direitos aos cidadãos simples, tão somente com o fito de não sobrecarregar o Judiciário. Sendo este, no entendimento deste aluno-autor, destarte, um argumento por si mesmo refutável. 


\section{CONCLUSÃO}

A problemática da adoção de Standards Sociais no âmbito da OMC é, como se observou, tema de elevada complexidade, por envolver múltiplas questões e interesses diversos.

O percurso histórico-analítico trilhado no presente estudo demonstra 0 inegável imbricamento e a relação de mútua influência existente entre o comércio internacional e as condições sociais e laborais fundamentais. Sendo este fator relevante para análise do conjunto do problema em apreço.

A implementação de padrões sociais mínimos em âmbito internacional parece ser condição indispensável à efetivação de direitos humanos básicos, assim como meio viável a garantir o fim último do comércio internacional (segundo os objetivos delineados pela própria $\mathrm{OMC}$ ): o desenvolvimento social e a progressiva melhoria das condições de vida. A inserção de Standards Sociais na OMC é, ademais, a formulação de um enfoque ético do comércio internacional.

No que tange ser, ou não, a OMC o melhor foro para a vinculação de tais Standards, esta é questão de fato delicada.

Em que pese não seja realmente o organismo ideal para a realização de tal escopo, a OMC parece, contudo, ser na atualidade o melhor foro para a consecução de tal empreitada.

Em primeiro lugar, por ser o organismo que melhor cumpriria a tarefa de tutelar os múltiplos interesses e fatores que permeiam a questão da cláusula geral, quais sejam: a tutela de direitos sociais e humanos basilares, a garantia de melhores condições no cenário produtivo e laboral, a promoção de um comércio internacional mais justo e leal, entre outros.

Parece, além disso, que tais cláusulas lograriam mesmo contribuir para a realização do objetivo de promover a melhoria das condições de vida, colimado pela Organização Mundial do Comércio.

Por último, mas não menos importante, pela sua inegável superioridade na capacidade de garantir maior teor de eficácia à implementação dos Standards Sociais, haja vista que a OMC detém um eficiente Sistema de Solução de Controvérsias e meios sancionadores eficazes, capazes de afiançar a efetividade da implementação das Cláusulas Sociais. É, também, o único organismo internacional que teria a real capacidade de, por meio dos efeitos positivos das cláusulas sociais, conceder incentivos ao comércio internacional dos estados, os quais seriam capazes de gerar substanciais benefícios econômicos aos países menos desenvolvidos, oferecendo, assim, uma contribuição efetiva à 

DEBATE.

concretização dos padrões sociais mínimos estipulados.

Também a vinculação das cláusulas sociais no plano do comércio internacional é meio idôneo a garantir a vedação ao retrocesso dos direitos sociais no domínio global, uma vez que, atualmente, ante os fenômenos de acirramento da concorrência comercial internacional e da ocorrência cíclica de crises econômicas, muitos países com um sistema de garantias dos direitos sociais mais desenvolvido têm se inclinado a reduzir os seus níveis de padrões sociais, a fim de aumentar o seu potencial competitivo.

No que diz respeito a quais Standards Sociais deveriam ser incluídos, compreende-se que os aqui abordados são aqueles que melhor congregariam, na realidade hodierna, os múltiplos objetivos e interesses ora em baila.

Não se acredita serem esses, todavia, numerus clausus, podendo ser incluídos outros padrões sociais básicos, desde que visando assegurar proteções sociolaborais indispensáveis à garantia da dignidade da pessoa humana e à melhoria das condições de vida, e causem objetiva melhoria nas relações do comércio internacional. Atentando sempre, além disso, às diferentes realidades conjunturais e estágios de desenvolvimento dos diversos estados quando da sua estipulação.

Nesse sentido, um exemplo que se crê ser pertinente é o da hipótese de, dados os primeiros passos no sentido de garantir os padrões mínimos supraelencados, se pensar em exigir condições mínimas de segurança e saúde notrabalho.

Entende-se, igualmente, que a eventual implementação de Cláusulas Sociais no âmbito do comércio internacional deve se dar de maneira a permitir uma progressiva adaptação dos estados aos padrões sociais estipulados. Sendo essa escala de progressiva adaptação rigidamente definida de acordo com a realidade socioeconômica de cada "grupo" de países (desenvolvidos, em desenvolvimento, ou subdesenvolvidos).

Compreende-se ainda que os Standards Sociais deveriam ser incluídos na sua forma positiva e negativa - prevendo, para além de sanções aos estados descumpridores dos Standards (forma negativa), benefícios/incentivos comerciais (forma positiva) àqueles países que não tendo ainda realizado a aplicação desses padrões o façam de modo mais eficaz que as metas de implementação progressiva estabelecidas, prestando, desse modo, auxílio efetivo ao crescimento econômico e ao desenvolvimento social desses países.

Dentre os vários meios de inserção das cláusulas sociais no acordo da OMC previstos pela doutrina, pugnou-se pela eleição daquele que permita uma mais ampla atuação e verificação por meio do Sistema de Solução de Controvérsias, 
com o fito de possibilitar a prevenção de eventuais abusos (como atuações protecionistas, por exemplo) por parte dos países desenvolvidos.

A proposta da doutrina de inclusão dos Standards Sociais por intermédio do Artigo XXIII (Anulação ou prejuízo de benefícios), assim como àquela apresentada pela CISL à de se proceder a uma interligação entre os processos de monitoramento e reclamação da OIT e o procedimento de reconciliação da OMC, parece, por sua vez, preencher satisfatoriamente tais requisitos.

Por derradeiro, conclui-se que, embora a inserção das cláusulas sociais nos acordos da OMC não alcance uma solução ótima paretiana ${ }^{69}$ para a vinculação de padrões sociais mínimos no âmbito internacional, essa parece ser, num sopesamento dos valores e interesses em jogo nesta temática, a melhor alternativa ora disponível para a consecução de tal desiderato.

\section{REFERÊNCIAS}

ALBERTO, Maria de Fátima Pereira; e SANTOS, Denise Pereira dos. Trabalho infantil e desenvolvimento: reflexões à luz de Vigotski. Disponível em: $<$ http://www.scielo.br/scielo.php?script=sci_arttext\&pid $=$ S | 4 |3737220l I000200004 > . Acesso em 6/6/2013;

BELLETTINI, Giorgio; CERONI, Carlotta Berti; e OTTAVIANO, Gianmarco I. P.. Child Labour and Resistance to Change; in Economica. London: LSE, Volume 72, Number 287, August -2005;

BOBBIO, Noberto. A Era dos Direitos. $9^{a}$ ed.. Rio de Janeiro: Elsevier, 2004;

CARNEIRO, Cristiane de Andrade Lucena. Disputas comerciais e magnanimidade: um estudo do mecanismo de solução de controvérsias da Organização Mundial de Comércio à luz da teoria dos movimentos. Contexto Internacional. Rio de Janeiro, v. 30, nº 3, dez. 2008;

\footnotetext{
${ }^{69}$ O ótimo ou eficiência de Pareto é um conceito de economia desenvolvido pelo italiano Vilfredo Pareto. Segundo esse conceito, uma situação é ótima se não for possível melhorar a situação, ou, mais genericamente, a utilidade de um agente, sem degradar a situação ou utilidade de qualquer outro agente.
} 
A INCLUSÃO DE STANDARDS SOCIAIS NOS ACORDOS DA OMC: UM ANTIGO, MAS AINDA CONTEMPORÂNEO DEBATE.

CHANG, T. Leslie. Factory Girls: From Village to City in a Changing China. New York: Spiegel \& Grau, 2009;

CUNHA, Luís Pedro. O Sistema Comercial Multilateral e os Espaços de Integração Regional. Coimbra: Coimbra Editora, 2008;

FRENCH, John D. . A busca de padrões de direitos trabalhistas no comércio internacional. Estudos Avançados. São Paulo, Vol. 10, n²7, ago. 1996;

KAWAY, Mina; e VIDAL, Pedro Walter G. Tang. Dumping Social: as Normas de Trabalho e sua relação com o Comércio Internacional. Disponível em: $<$ http://www.declatra.com.br/MyFiles/Artigos/Artigo\%20Cl\%C3\%Al usula\% 20Social.pdf > . Acesso em 23/5/20 I3;

KRAMER, Cynthia. Medidas antidumping: devido processo legal à luz das regras da OMC. Tese (Doutorado em Direito Internacional) - Faculdade de Direito, Universidade de São Paulo, São Paulo, 20 I2;

LAFER, Celso. A OMC e a regulamentação do comércio internacional: uma visão brasileira. Porto Alegre: Livraria do Advogado, 1998;

MACHADO, Jónatas E. M.. Direito Internacional: Do paradigma clássico ao pós-I I de setembro. $3^{\mathrm{a}}$ ed. . Coimbra: Coimbra Editora, 2006;

MATOS, Eurico Daniel Lagoa de. Oligarquia: Governação Económica e Ordem Internacional desde 1975. Disponível em: $<$ https://estudogeral.sib.uc.pt/jspui/bitstream/I03 | 6// I 867/I/Disserta\%c3\% a7\%c3\%a3o\%20de\%20Mestrado\%20de\%20Eurico\%20Matos.doc>. Acesso em 3/6/20 I3;

MENEGUIN, Fernando Boarato; e AMARO, Meiriane Nunes. Política de salário mínimo: efetividade, condicionantes e alternativas. Disponível em: <http://www2. senado.leg.br/bdsf/bitstream/handle/id/834/RI 5703. pdf? sequence $=4>$. Acessado em: 28/05/2013;

MONTAÑÁ MORA, Miquel. La OMC y el Reforzamiento del Sistema GATT. Madrid: McGraw-Hill, 1997; 
OLIVEIRA, Ivan Tiago Machado. A ordem econômico-comercial internacional: uma análise da evolução do sistema multilateral de comércio e da participação da diplomacia econômica brasileira no cenário mundial. Disponível em: <http://www.scielo.br/scielo.php?script=sci_arttext\&pid = S0 I 028529200700020000 I > . Acesso em 3/6/20 I3;

PORTELA, Paulo Henrique Gonçalves. Direito Internacional Público e Privado. $3^{\mathrm{a}}$ ed. Salvador: JusPodivm, 20 I I;

QUEIROZ, Maria do Socorro A. de. A Cláusula Social na OMC: por uma interrelação efetiva entre OMC e OIT e o respeito aos Direitos Fundamentais dos Trabalhadores. SCIENTIAIURIS, Londrina, v. I I, pp. I65- I83, 2007;

REICHERT, Tobias. Padrões sociais na economia mundial. Disponível em: $<\mathrm{h}$ t $\mathrm{t}$ p : / / w w w c o c - r u n d e r tisch.de/inhalte/publikationen_rt/Social_standards_global_economy_port.pdf $>$. Acesso em 22/5/2013;

REIS, Jair Teixeira dos. Organização Mundial Do Comércio - OMC e o Direito do Trabalho. Disponível e m: <http://sisnet.aduaneiras.com.br/lex/doutrinas/arquivos/l 60 l 07.pdf >. Acesso em 22/5/2013;

RESENDE JÚNIOR, Vicente de Paula Mendes de. A inserção da Cláusula Social na Organização Mundial do Comércio: uma análise sobre a associação entre o comércio internacional e os padrões mínimos de condição de trabalho. Disponível em: <http://www.bdtd.ucb.br/tede/tde_arquivos/9/TDE-20 I3$\begin{array}{llllllllllllll}0 & 4 & - & 0 & \text { I } & \mathrm{T} & 0 & 7 & 0 & \overline{8} & 3 & 2 & \mathrm{Z} & -\end{array}$ I 547/PublicoNicente\%20de\%20Paula\%20Mendes\%20de\%20Resende\%20 Junior.pdf>. Acesso em 23/5/20 I3;

SEN, Amartya. Desenvolvimento como Liberdade. São Paulo: Companhia de Bolso, 2012;

SENA JÚNIOR, Roberto Di. Comércio Internacional e Padrões Trabalhistas: a Falácia do Discurso Humanitário. Revista Seqüência. N. ${ }^{\circ}$ 46, pp. 12 I - | 40, jul. de 2003; 

DEBATE.

SILVA. Eveline de Andrade Olivera e. A Cláusula Social no Direito Internacional Contemporâneo. Disponível em: <http://repositorio.uniceub.br/bitstream/I 23456789//490/I/EVELINE.pdf> . Acesso em 23/5/2013;

THORSTENSEN, Vera. A OMC - Organização Mundial do Comércio e as negociações sobre comércio, meio ambiente e padrões sociais. Revista Brasileira de Política Internacional. Brasília, v. 4I , n. 2, Dec. 1998;

TIMM, Luciano Benetti (organ.). Direito e Economia no Brasil. São Paulo: Editora Atlas, 20 I2;

VARELLA, Marcelo Dias. Efetividade do Órgão de Solução de Controvérsias da Organização Mundial do Comércio: uma análise sobre os seus doze primeiros anos de existência e das propostas para seu aperfeiçoamento. Revista Brasileira de Política Internacional. 2009, Vol. 52, n² 2;

YOSHIURA, Jackson Apolinário. O Sistema de Soluções de Controvérsias da OMC: A aplicação Coativa do Direito. Revista Eletrônica de Direito Internacional. Vol. 6, 20। 0, pp. I52-189.

BRASIL. Direitos do Trabalhador: Salário Mínimo. Disponível em: <http://www.brasil.gov.br/para/servicos/direitos-do-trabalhador/salariominimo > . Acesso em 4/6/20/3;

ORGANIZAÇÃO INTERNACIONAL DE NORMALIZAÇÃO. Cit. conforme ABNT, ISO/IEC. Guia 2 - Normalização e Atividades Relacionadas Vocabulário Geral; 1998;

ORGANIZAÇÃO INTERNACIONAL DO TRABALHO. Convenção ( I 05) sobre a Abolição do Trabalho Forçado ou Obrigatório. Disponível em: <http://www.ilo.org/dyn/normlex/en/??p=NORMLEXPUB: I 2 1 00:0::NO: I 2 I00:PI 2 I00_INSTRUMENT_ID:3 I2250:NO>. Acesso em 6/6/20 I3;

ORGANIZAÇÃO INTERNACIONAL DO TRABALHO.. Convenção (29) sobre o Trabalho Forçado ou Obrigatório. Disponível em: $<$ http://www.oit.org.br/sites/all/forced_labour/oit/convencoes/conv_29.pdf > . Acesso em 6/6/2013; 
ORGANIZAÇÃO MUNDIAL DO COMÉRCIO. Acuerdo de Marrakech por el que se establece la Organización Mundial del Comercio. Disponível em: <http://www.wto.org/spanish/docs_s/legal_s/04-wto_s.htm>. Acesso em 5/6/2013;

ORGANIZAÇÃO MUNDIAL DO COMÉRCIO. Agreement on Implementation of Article $\mathrm{VI}$ of the General Agreement on Tariffs and Trade 1994. Disponível em: <http://www.wto.org/english/docs_e/legal_e//9adp_0l_e.htm>.Acesso em 3/7/2013;

ORGANIZAÇÃO MUNDIAL DO COMÉRCIO. Conferencia de las Naciones Unidas sobre Comercio y Empleo. Disponível em: $<\mathrm{Http}: /$ Www.wto.org/spanish/docs_s/legal_s/havana_s.pdf $>$. Acesso em 22/5/20।3;

ORGANIZAÇÃO MUNDIAL DO COMÉRCIO. Declaración ministerial de Sing a p r. Disponível e m : <http://www.wto.org/spanish/thewto_s/minist_s/min96_s/wtodec_s.htm >. Acesso em 4/6/2013;

ORGANIZAÇÃO MUNDIAL DO COMÉRCIO. General Agreement on Tariffs and Trade. Disponível e m: <http://www.wto.org/english/docs_e/legal_e/gatt47_e.pdf>. Acesso em 22/5/20।3;

ORGANIZAÇÃO MUNDIAL DO COMÉRCIO. Introducción al sistema de solución de diferencias de la OMC. Disponível em: $<$ http://www.wto.org/spanish/tratop_s/dispu_s/disp_settlement_cbt_s/cls lp I_s.htm >. Acesso em 4/6/2013;

ORGANIZAÇÃO MUNDIAL DO COMÉRCIO. Members and Observers. D i s p o níve I e m: $<$ http://wto.org/english/thewto_e/whatis_e/tif_e/org6_e.htm>. Acesso em 22/5/2013;

ORGANIZAÇÃO MUNDIAL DO COMÉRCIO. The Doha Round. Disponível em: <http:/www.wto.org/english/tratop_e/dda_e/dda_e.htm>. Acesso em 23/5/20।3; 
ORGANIZAÇÃO MUNDIAL DO COMÉRCIO. The GATT years: from $\mathrm{H}$ a vana to Marrakesh. Disponível e m : <http://www.wto.org/english/thewto_e/whatis_e/tif_e/fact4_e.htm>. Acesso em 22/5/20।3;

ORGANIZAÇÃO MUNDIAL DO COMÉRCIO. What we do. Disponível em: <http://www.wto.org/english/thewto_e/whatis_e/what_we_do_e.htm > . Acesso em 23/5/2013;

UNIÃO EUROPÉIA. Community Charter of Fundamental Social Rights of Workers. Disponível e m: $<$ http://europa.eu/legislation_summaries/employment_and_social_policy/anti discrimination_relations_with_civil_society/cl0107_en.htm>. Acesso em 5/6/2013;

UNICEF. Factsheet: Child Labour. Disponível em: $<$ http://www.unicef.org/infobycountry/files/child_labour.pdf>. Acesso em 6/6/2013. 


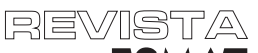

ESMAT 